\title{
ARCOBACTER BUTZLERI: FIRST ISOLATION REPORT FROM CHICKEN CARCASSES IN COSTA RICA
}

\author{
Maria Laura Arias ${ }^{1 *}$, Adriana Cid ${ }^{1}$, Heriberto Fernandéz ${ }^{2}$
}

${ }^{1}$ Faculty of Microbiology. Universidad de Costa Rica. San José. Costa Rica; ${ }^{2}$ Institute of Clinical Microbiology. Universidad Austral de Chile. Valdivia. Chile.

Submitted: January 06, 2010; Returned to authors for corrections: April 23, 2010; Approved: August 23, 2010.

\begin{abstract}
Arcobacter butzleri isolation from chicken carcasses in Costa Rica is reported for the first time. The isolated strains ( $\mathrm{P}$ and $\mathrm{R}$ ) were presumptively identified by their phenotypic characteristics. Definitive identification was made using a multiplex PCR assay for the simultaneous detection and identification of Arcobacter butzleri, Arcobacter cryaerophilus and Arcobacter skirrowii.

These first isolations indicate the necessity of further investigation about the prevalence, distribution, ecology and interactions with human beings of this and other Arcobacter species.
\end{abstract}

Key words: Arcobacter butzleri, chicken carcasses, isolation, epidemiology

The genus Arcobacter, belongs to the family Campylobacteraceae, class Proteobacteria, subclass Gracillicutes and comprises polar flagellates, spirally, curved, Gram negative rods formerly known as aerotolerant Campylobacter-like organisms (4).

The first isolates were obtained by Ellis et al. (5) from aborted bovine fetuses. Further studies related these microorganisms with mastitis and abortion in the bovine, ovine, equine and porcine species $(4,15)$.

Currently, the genus Arcobacter comprises the following species: A. cryaerophilus, A. butzleri, A. skirrowii, A. nitrofrigilis, A. cibarius, A. halophilus, A. mytili, A. thereius, A. marinus and the "Candidatus A. sulfidicus" (1, 9, 13). At present, A. butzleri is considered the most common species of the genus being considered as a zoonotic and emerging foodborne pathogen that could be associated with bacteremia and human diarrheic illness. It has been also isolated from food of animal origin, especially from poultry, carcasses and offal, milk, mussels, as well as from water bodies, sewage and fecal samples of different animal species $(6,7,12,17,19)$.

In Latin America little information about Arcobacter species is available, being isolated in Chile $(6,7)$, Argentina (8), Brazil (3) and Mexico (18). In order to provide additional information about the occurrence of $A$. butzleri in different parts of the world, we report here the first isolation of this zoonotic and emerging foodborne pathogen from chicken carcasses in Costa Rica.

During the search of Campylobacter spp. in chicken carcasses, from two pre-enriched samples seeded on cefoperazone charcoal deoxycholate agar (CCDA), a commercial blood free medium for the isolation of $C$. jejuni, $C$. coli, C. upsaliensis and C. lari at $37^{\circ} \mathrm{C}$, little pinpoint, translucent colonies were isolated. These colonies differed from the characteristics gray, moist, flat-spreading colonies 
of Campylobacter. However, Gram stain and wet mount observations under phase contrast microscopy revealed Gram negative curved bacilli with rapid darting and corkscrew-like motility, respectively, being also catalase and oxidase positive. Growth tests at $25^{\circ} \mathrm{C}$ and $37^{\circ} \mathrm{C}$ in aerobic atmosphere and at $42^{\circ} \mathrm{C}$ in microaerobic atmosphere were performed. Positive results were obtained only at the two first conditions. These results allowed presumptive indetification of isolates as Arcobacter sp. Strains were identified phenotypically as $A$. butzleri using the standard tests described in Table 1 (1). Definitive identification was made using the multiplex polymerase chain reaction $(m$-PCR) proposed by Houf et al. (Fig.1) (11), confirming that both strains (strain P and strain R) corresponded to the species A. butzleri.

Table 1. Differential characteristics of three zoonotic Arcobacter species and Campylobacter jejuni

\begin{tabular}{lcccc}
\hline Characteristic & A. cryaerophilus & A. butzleri & A. skirrowii & C. jejuni \\
\hline Oxidase & + & + & + & + \\
Catalase & + & + & $\mathrm{V}$ & + \\
Nitrate reduction & + & + & + & + \\
Hyppurate hydrolisis & - & - & + & + \\
Indoxyl acetate hydrolisis & + & + & + \\
Growth in: & & + & - \\
Air at $25^{\circ} \mathrm{C}$ & + & - & - \\
$4 \%(\mathrm{~W} / \mathrm{V}) \mathrm{NaCl}$ & - & + & - \\
Mac Conkey agar & $\mathrm{V}$ & + & + \\
Resistance to: cephoperazone $\left(64 \mathrm{mgl}^{-1}\right)$ & + & & + \\
\hline
\end{tabular}

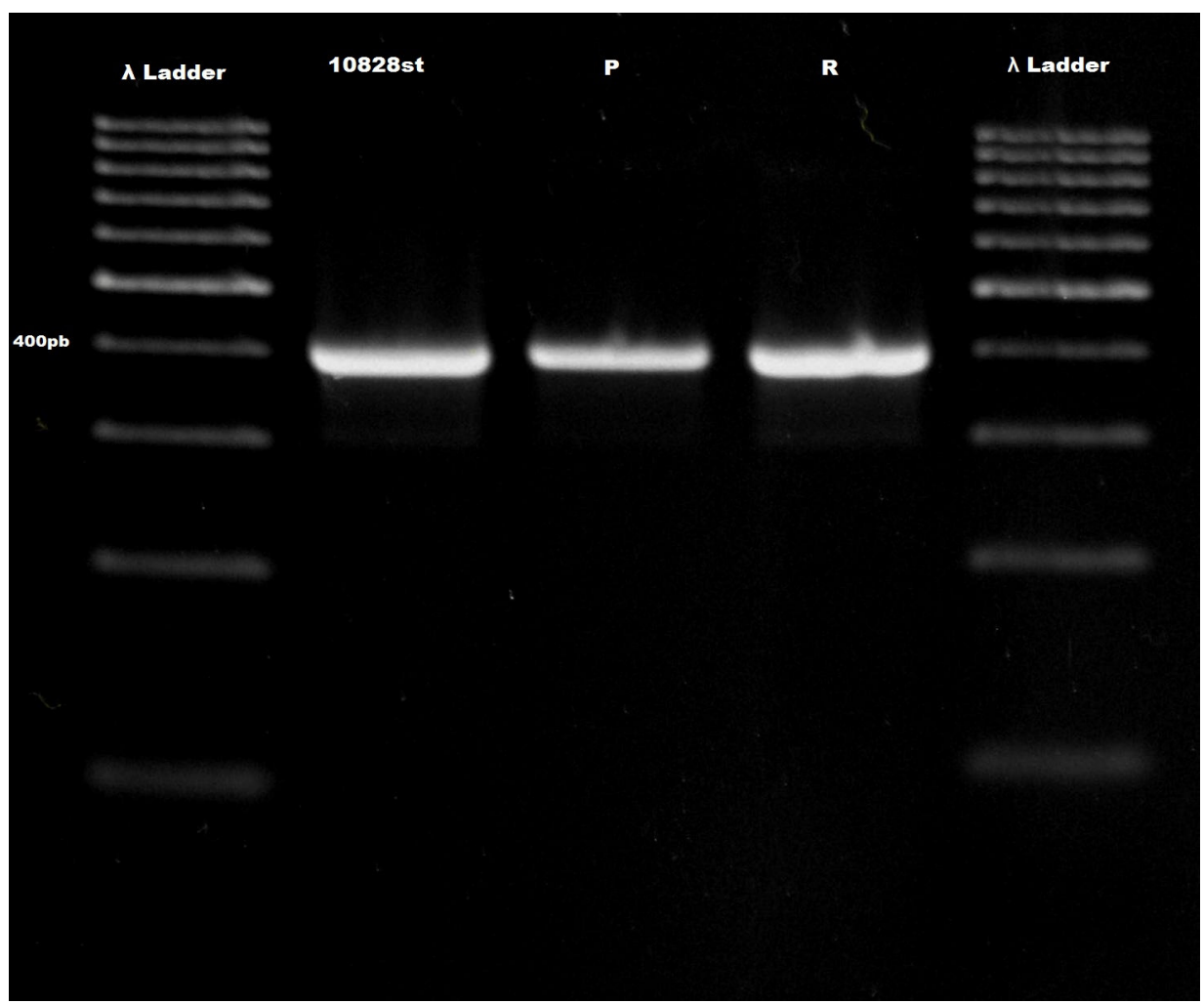

Figure 1. First lane: 100-bp ladder; second lane: A. butzleri 10828st reference strain; third lane: strain P; fourth lane: strain R; fifth lane: 100bp ladder. 
A. butzleri is an emerging pathogen that has been associated with abortion and enteritis in animals and with diarrhea and bacteremia in adults and children. This Arcobacter species seems to be the most frequent in human beings. A. butzleri recognizes a wide reservoir range, being isolated from domestic and free living mammals and birds, from retail chicken meat, from shellfish and environmental water bodies as well. It has been suggested that water and chicken meat may play an important role in the transmission of these organism $(6,7,12,14,16)$.

At present no standard isolation method for Arcobacter has been proposed, however there is consensus that an enrichment step and the use of antimicrobials are necessary for this purpose $(2,9,14)$.

The first strains of A. butzleri isolated from chicken meat in Costa Rica grew in CCDA after a previous enrichment period of $24 \mathrm{~h}$ in Bolton broth, both incubated in microaerobic conditions at $37^{\circ} \mathrm{C}$. This is not surprising because A. butzleri is resistant to the antimicrobials present in both media $(2,14)$. Furthermore, arcobacters are able to grow under aerobic and anaerobic conditions over a wide temperature range $\left(15-37^{\circ} \mathrm{C}\right)$ but optimal growth occurs under microaerobic conditions (3$\left.10 \% \mathrm{O}_{2}\right)(4)$.

Correct identification of arcobacters is not easy, and too often, arcobacters are misidentified as campylobacters, especially when phenotypical methods are applied. Due to their relative metabolic inertness biochemical identification of arcobacters is not recommended (9) being necessary the use of some molecular techniques such as the $m$-PCR described by Houf et al. (11). As shown in Fig 1, both strains amplified a 401-bp fragment, specific for A. butzleri. No PCR product was generated for other Arcobacter species.

Like for Campylobacter, a high prevalence of $A$. butzleri is observed on chicken carcasses $(9,14,16)$. The first isolation of A. butzleri from chicken carcasses in Costa Rica not only reveals the presence of this bacterium in our country but, due their potential importance for public health, also creates the necessity of further investigation about the prevalence, distribution, ecology and interactions with human beings of this and other Arcobacter species.

\section{ACKNOWLEDGMENTS}

This work was partially supported by the DID-UACh Grant SE-1-2009

\section{REFERENCES}

1. Collado, L.; Cleenwerck, I.; Van Trappen, S.; De Vos, P.; Figueras, M. J. (2009). Arcobacter mytili sp. nov., an indoxyl acetate hydrolysis negative bacterium isolated from mussels. Int. J. Syst. Evol. Microbiol. 59, 13911396.

2. Corry, J.E.L.; Atabay, H.I. (1997). Comparison of the productivity of cefoperazone amphotericin teicoplanin (CAT) agar and modified charcoal cefoperazone deoxycholate (mCCD) agar for various strains of Campylobacter, Arcobacter and Helicobacter pullorum. Int. J. Food Microbiol. 38: 201-209.

3. De Oliveria S.J.; Wesley, I.V.; Baetz, A.L.; Harmon, K.M.; Kader, I.I.T.A.; de Uzeda, M. (1999). Arcobacter cryaerophilus and Arcobacter butzleri isolated from preputial fluid of boars and fattening pigs in Brazil. J. Vet. Diagn. Invest. 11, 462-464.

4. Debruyne, L.; Gevers, D.; Vandamme, P. (2008). Taxonomy of the Family Campylobacteraceae, p. 3-26. In Nachamkin I.; Szymansky, C.M.; Blaser, M.J. (ed.), Campylobacter Third Edition. ASM Press, Washington, DC.

5. Ellis, W.A.; Nelly, S.D.; O’brien, J.J.; Ferguson, H.W.; Hanna, J. (1977). Isolation of Spirillum/ Vibrio-like organisms from bovine fetuses. Vet. Rec. 100, 451-452.

6. Fernández, H.; Krause, S.; Villanueva, M.P. (2004). Arcobacter butzleri an emerging enteropathogen: communication of two cases with chronic diarrhea. Braz. J. Microbiol. 35, 216-218.

7. Fernández, H.; Vera, F.; Villanueva, M.P. (2007). Arcobacter and Campylobacter species in birds and mammals from southern Chile. Arch. Med. Vet. 39:, 163-165.

8. Giacoboni, G.; Moredo, F.; Tobía, M.; Piazza, D. (1997). Aislamiento de bacterias del género Arcobacter con características bioquímicas de $A$. crioaerophilus en aguas del Río de la Plata. Analecta Vet. 17, 19-21.

9. Houf, K. (2009). Arcobacter in a food safety perspective. Arch. Lebensmittelhyg. 60: 73-76.

10. Houf, K. ; On, S. ; Coenye, T., Debruyne, L. ; De Smet, S. ; Vandamme, P. (2009). Arcobacter thereius sp. nov., isolated from pigs and ducks. Int. 
J. Syst. Evol. Microbiol. 59, 2599-2604.

11. Houf, K.; Tutenel, A.; De Zutter, L.; Van Hoof, J.; Vandamme, P. (2000). Development of a multiplex PCR assay for the simultaneous detection and identification of Arcobacter butzleri, Arcobacter cryaerophilus and Arcobacter skirrowii. FEMS Microbiol. Lett. 193, 8994.

12. Jacob, J.; Woodward, D.; Feuerpfeil, I.; Johnson, W.M. (1998). Isolation of Arcobacter butzleri in raw water and drinking water treatment plants in Germany. Zbl. Hyg. Umweltmed. 201, 189-198.

13. Kim, H.M.; Hwang, C.Y.; Cho, B.C. (2009). Arcobacter marinus sp. nov. Int. J. Syst. Evol. Microbiol. (In press).

14. Lehner, A.; Tasara, T.; Stephan, R. (2005). Relevant aspects of Arcobacter spp. as potential foodborne pathogen. Int. J. Food Microbiol. 102: $127-135$.
15. Logan, E.F.; Neil, S.D.; Mackie, D.P. (1982). Mastitis in dairy cows associated with an aerotolerant Campylobacter. Vet. Rec. 110, 229-230.

16. Mansfield, L.P.; Forsythe, S.J. (2000). Arcobacter butzleri, A. skirrowii and A. cryaerophilus - Potential emerging human pathogens. Rev. Med. Microbiol. 11, 161-170.

17. Pianta, C.; Thompsen Passos, D.; Hepp, D.; de Oliveira, D.J. (2007). Isolation of Arcobacter spp. from the milk of dairy cows in Brazil. Ciência Rural, Santa Maria. 37: 171-174.

18. Villarruel-López, A.; Márquez-González, M.; Garay-Martínez, L.E.; Zepeda, H.; Castillo, A.; Mota de la Garza, L.; Murano, E.A.; TorresVitela R. (2003). Isolation of Arcobacter spp. from retail meats and cytotoxic effects of isolates against vero cells. J. Food Prot. 66, 13741378. 